\title{
Electrophoretic Patterns of Soluble Proteins in Tobacco Leaf During Curing*
}

\author{
by S. J. Sheen and B. I. Townes \\ Department of Agronomy, University of Kentucky, Lexington, Kentucky, USA
}

\section{INTRODUCTION}

Tobacco leaf quality is affected by varieties, growth environment, and post-harvesting treatments. Of the latter, curing and aging are the two major phases during which changes of chemical composition may take place. Enzymatic activity initially present in harvested leaves is believed to be responsible for the major chemical changes occurring during curing. For this reason, the kind and quantity of soluble proteins in tobacco leaves during curing have been extensively investigated in the past $(5,10,16)$. More than one-half of the soluble leaf protein is known to be lost during curing. In spite of this sharp decrease, phosphatase, invertase, and peroxidase activities remain relatively constant in cured leaves (I). By ultracentrifugation tobacco leaf extracts can be separated into two protein fractions, namely Fraction I and Fraction II (13). The latter contains considerable activities of various enzymes, whereas the former possesses the properties of D-ribulose- 1,5 -diphosphate carboxylase (4). Fraction I protein consists of two kinds of subunits of high molecular weight and exists wherever chlorophyll a is present. It is rapidly broken down after the leaves are detached, and disappears after eight days of air-curing; however, appreciable amounts of Fraction II protein are present (10). It appears that leaf senescence or curing involves the change of protein components which are directly associated with physiological functions. The number of proteins soluble in aqueous medium should be enormous because of the complexity of metabolic systems in the leaf, and polyacrylamide gel electrophoresis would be a sensitive method to separate the major soluble proteins. This paper presents (i) the electrophoretic zymograms of soluble leaf proteins from different tobacco types, (ii) their pattern of change during simulated aircuring conditions, and (iii) the relationship of soluble proteins with cell fractions. In addition, the chemical composition of certain protein bands was partially characterized by histochemical methods.

\footnotetext{
* Journal Paper No. 70-3-141, Kentucky Agricultural Experiment Station, Lexington, Kentucky. Contribution from the Department of Agronomy, University of Kentucky.

Received for publication: 27th October, 1970.
}

\section{MATERIALS AND METHODS}

Six double-haploid lines of tobacco (Nicotiana tabacum L.), which were developed by colchicine treatment (15) and maintained at the Kentucky Agricultural Experiment Station, and a commercial variety Burley $2 I$ were employed in this investigation. Among the doublehaploid lines, two were burleys, Ky Iso I Ky 16 and Ky Iso 3 Burley 37; two were flue-cured tobaccos, $\mathrm{Ky}$ Iso 4. Hicks and $\mathrm{Ky}$ Iso 6 F.C. 402; one was a firecured type, Ky Iso $2 \mathrm{Ky} \mathrm{I5I}$; and one was a Turkish strain, Ky Iso 7 Turkish. About 50 mature leaves from field grown plants of each of the above lines were primed at the seventh or eighth stalk position and subjected to simulated air-curing conditions in an environmental chamber in darkness. The temperature in the chamber was maintained at $24 \pm 1^{\circ} \mathrm{C}$ and the relative humidity remained $68 \pm 2 \%$ according to the method of Pogell et al. (10). During the course of air-curing, leaf discs of $5 \mathrm{~cm}$ in diameter were removed at the following intervals: at harvest, $1 / 2,1,2,4,6,10$, and 17 days. The leaf discs were collected from eight sampling areas, four on either side of the midrib. On each of the sampling dates, one leaf disc was taken from each leaf in such a way that the samples were composed of eight sampling areas in an equal proportion. All leaf discs were treated in liquid nitrogen prior to freeze-drying and later ground to pass through a 40-mesh screen in a Wiley mill. Samples were stored in amber bottles at $-10^{\circ} \mathrm{C}$.

Soluble leaf proteins were extracted by two different methods. In the first method, leaf powder was ground in a cold mortar in o.I M Tris- $\mathrm{HCl}$ buffer, $\mathrm{pH} 8$, and centrifuged at $20,000 \times \mathrm{g}$ for one hour, a procedure similar to that described previously (12). The second method employed homogenizing tissues in o.I $\mathrm{M}$ phosphate buffer, $\mathrm{pH}$ 7.2, containing 0.01 M 2-mercaptoethanol and precipitating proteins from the supernatant fluid with $70 \%$ saturation of $\left(\mathrm{NH}_{4}\right)_{2} \mathrm{SO}_{4}$. Protein precipitate was dialyzed against several changes of icewater in a cold room. The dialysate was concentrated by dehydration in polyethylene glycol 600o. Approximately 100 to $150 \mu \mathrm{g}$ protein as determined by Lowry's method (7) was applied onto each polyacrylamide gel 
column. Disc electrophoretic procedure described by Davis (2) with $7.5 \%$ polyacrylamide gel and Trisglycine buffer, $\mathrm{pH}$ 8.5, was followed. Each gel column was subjected to a current of $2.5 \mathrm{ma}$ for 1.5 hours in a refrigerator at $4{ }^{\circ} \mathrm{C}$. Soluble protein patterns were visualized by staining the gels in a $0.5 \%$ amido black in $7 \%$ acetic acid solution for one hour and subsequently destaining at 12 ma current per tube using $7 \%$ acetic acid as buffer. A side-by-side comparison of protein bands in different tobacco types was also performed by polyacrylamide gel block electrophoresis as described elsewhere (12).

Cellular localization of soluble proteins was conducted by analyzing banding patterns of cell fractions. Immature green leaves of Burley $2 I$ were used as the experimental material. In order to minimize as much as possible disruption of cellular organelles, the method of Spencer and Wildman (14) was followed. Leaf lamina were cooled and chopped to a fine mince with a sharp paper cutter. The leaf mince was extracted with a sucroseTris medium consisting of $0.4 \mathrm{M}$ sucrose, $0.05 \mathrm{M}$ Tris buffer, $\mathrm{pH} 7.8,6.9 \mathrm{mM}$ magnesium acetàte, $10.3 \mathrm{mM}$ $\mathrm{KCl}$, and $3.9 \mathrm{mM}$ 2-mercaptoethanol. The resulting extract was filtered through three layers of cheesecloth. The filtrate was centrifuged for $5-10 \mathrm{~min}$ at $10,000 \times \mathrm{g}$ twice. The supernatant fluid (supernatant I) was centrifuged at $10,000 \times \mathrm{g}$ for $20 \mathrm{~min}$ to yield mitochondrial fraction, while the resulting supernatant fluid was identified as supernatant II. The pellet obtained from low-speed centrifugation was spun for $2 \mathrm{~min}$ at $1,000 \times \mathrm{g}$ to produce a stratified pellet consisting of a green upper layer (chloroplasts), a white middle layer (starch granules and crystals) and a grey bottom layer (mainly nuclei). The green layer was carefully resuspended in the same extraction medium and then spun again at $1,000 \times g$ for 5 minutes. This process was repeated several times to produce a green pellet virtually free of starch granules. The purification of nuclear fraction was conducted in a similar manner. Microscopic examination confirmed the rich content of intact chloroplasts and nuclei in the respective fractions. All cellular fractions were lyophilized to dryness or reduced in volume. Soluble proteins were extracted by the first method as mentioned above. Electrophoresis and protein detection were the same procedure. Crude extracts of Burley $2 I$ leaf lamina were included for comparison.

Soluble protein bands were partially characterized by incubating gels in periodic-acid Schiff's reagent (PAS) or in colloidal iron solution. The former is specific for neutral mucopolysaccharides, whereas the latter strains acid mucopolysaccharides (8). In addition to these staining techniques, some gels were pretreated with $2 \%$ trypsin in o.I $\mathrm{M}$ phosphate buffer, $\mathrm{pH} 7.8$, at $40^{\circ} \mathrm{C}$.

\section{RESULTS AND DISCUSSION}

Figure $I$ shows the leaf protein zymograms of four tobacco strains representing burley, flue-cured, firecured, and Turkish types. Banding differences were not
Figure 1. Polyacrylamide disc-gel electrophoretograms of soluble proteins in mature leaves of four tobacco lines.

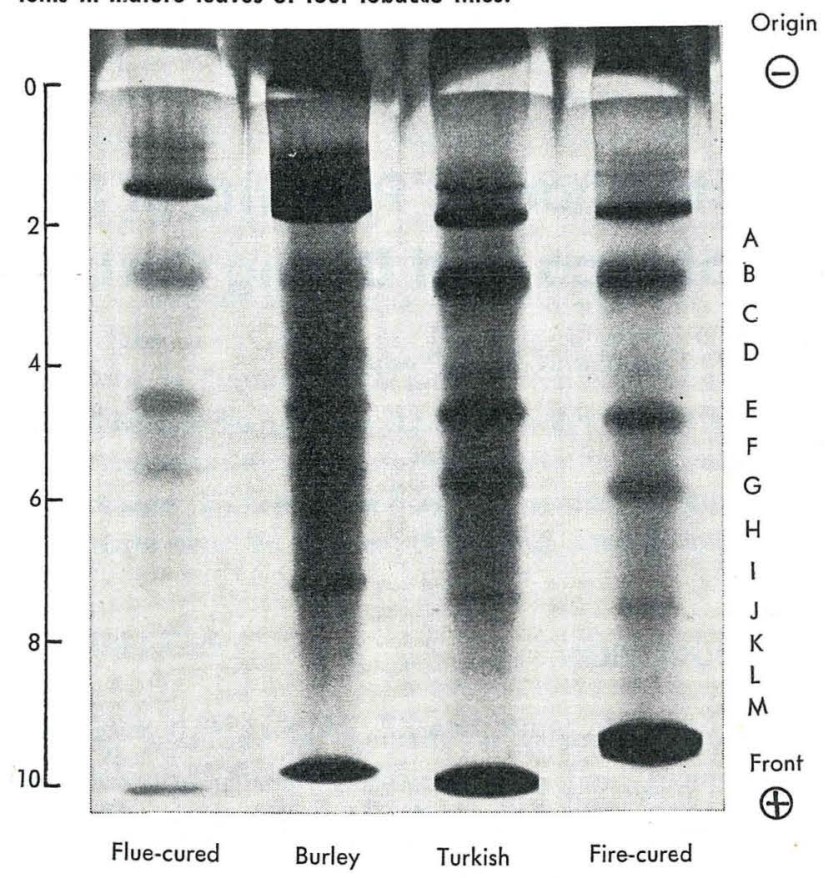

observed when comparison was made among the three burleys or two flue-cured lines. Crude leaf extracts and ammonium sulfate protein preparations yielded identical results. A thick band and at least two minor ones near the origin are likely aggregates. These bands appeared in higher concentration in burleys than in the other tobacco types studied. The fast-migrating band was apparently a pigment-protein complex and was used as a reference for calculating relative mobilities of slowmoving bands. By excluding these protein aggregates there are at least 13 visible bands tentatively designated as bands $A$ to $M$ in an order of increasing mobility. Narise and Sakai (9) have detected 14 protein bands in the mature tobacco leaves sampled at middle stalk positions. The present results showed that bands $B, E$, $G$, and J were very intense and appeared to be common to all four tobacco types. This was further confirmed by comparing protein extracts side by side on acrylamide gel blocks. Whether these bands are individual entities or clusters of proteins cannot be determined by the present electrophoretic technique. Among the tobaccos studied, the weak protein bands varied slightly in mobility and in number. Their appearance and mobility were somewhat affected by the amount of protein applied to the gel column. High protein concentrations resulted in a streaking phenomenon that masked the presence of weak bands. Recently, Honold and Stahmann (3) have shown that, in the presence of a hydrogen donor, peroxidase and polyphenol oxidase induced a smeared electrophoretic pattern with soluble proteins. Since tobacco leaves contain these oxidases as well as an excessive amount of polyphenols (12), difficulty in resolving soluble protein patterns would be expected. Moreover, the relative mobility of some proteins in the gel may be altered if they are aggregated with oxidized polyphenols.

Soluble protein patterns at various intervals of aircuring were similar for all seven tobacco strains. The 
Figure 2. Changes of the soluble profein patterns of Burley 21 leaves during air-curing.

Banding intensity illustrated in the diagram follows a decreasing order: solid band, striped band, solid line, and broken line.

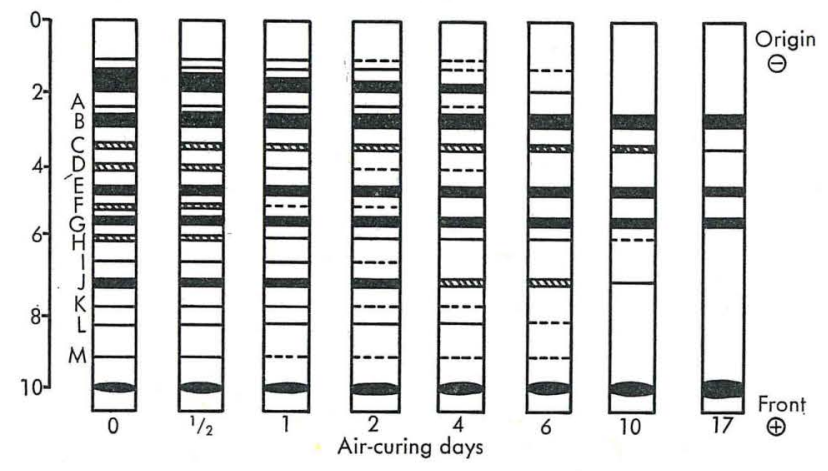

zymograms of Burley 21 (Fig. 2) will be used for illustration. The decrease in number of bands as a function of curing days is in keeping with other reports, and it has been suggested that a large proportion of soluble proteins are broken down during curing $(5,10$, 16). After 17 days of curing, bands $B, E$, and $G$ remained intense but band $C$ became very light. The remaining protein bands were not detectable. Doubling the protein concentration merely increased the intensity of these four bands without the appearance of others. These results indicate that tobacco leaf proteins differ in stability. This is consistent with the ultracentrifugal results reported by Pogell (IO) that protein Fraction I disappeared by the eighth day, while Fraction II was still present at the termination of air-curing. In the present study, the heavy bands at the cathode completely disappeared by the tenth curing day. These slowmoving proteins may correspond to the high molecular weight components of Fraction I protein. During the early phase of curing, bands $A, D$, and $F$ as well as $\mathrm{H}$ to $\mathrm{M}$ also drastically decreased in intensity. In contrast, bands B, C, E, and G exhibited a high degree of stability which coincides with the characteristics of Fraction II. With the use of starch-gel electrophoresis Kawashima et al. (5) found more than five components in Fraction II. However, they did not describe whether these bands were cathodic or anodic nor did they give their relative mobilities; therefore, comparison cannot be made.

Strong activities of pectin methylesterase, phosphatase, invertase, and peroxidase in cured tobacco leaves have been reported $(1,10)$. Major anodic peroxidases have a relative mobility greater than 0.59 and are detectable in air-cured leaves (II, I2). The absence of visible bands of fast mobility in the present study suggests that soluble enzymes in crude tobacco leaf extracts may not be detected as discrete protein bands. Strong cathodic peroxidases were also present in cured leaves (12), but the present electrophoretic procedure detected only those proteins migrating toward the anode.

When acrylamide gel columns were subjected to the PAS staining, bands, B, E, and G produced a positive reaction (purple bands). This was consistent for all tobacco strains studied and reproducible irrespective of curing intervals. A pretreatment of gel column with
Figure 3. Soluble protein patferns of Burley 21 leaf lamina extract, chloroplast extraci, and cytoplasmic fraction.

Illustration of banding intensity is the same as Fig. 2.
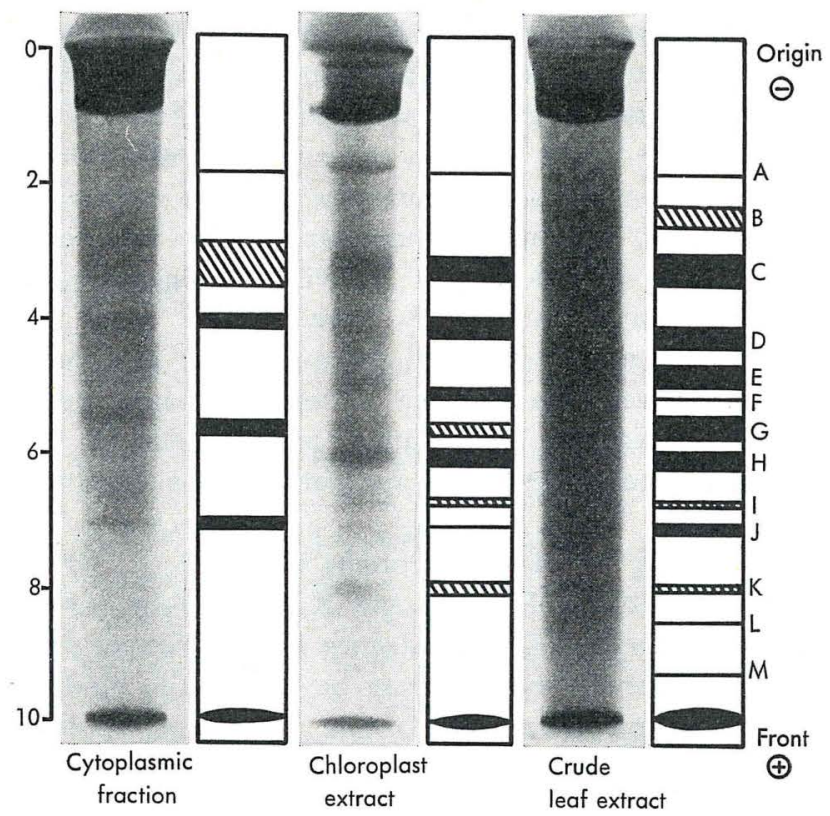

$2 \%$ trypsin for to minutes abolished the PAS positive reaction. The trypsin treatment also resulted in a complete loss of protein bands detectable with amido black dye. This leads to the conclusion that the three major protein bands $B, E$, and $G$ contain polysaccharides and are possibly glycoproteins. Colloidal iron staining showed light blue streaking in the gels but resolved no specific bands. This negative result suggests that these protein bands do not contain phosphate and/or sulfate moieties; the latter is commonly present in acidic mucopolysaccharides.

Some contrasts in protein patterns existed between the cytoplasmic fractions and organelle extracts, but were not evident among the three organelles studied. For this reason, only the banding patterns of crude leaf extract, chloroplast fraction, and supernatant II are given in Fig. 3. The presence of mitochondria in supernatant I did not alter the banding pattern when it was compared with that of supernatant II. This may be explained due to the fact that the polyacrylamide gel matrix was not spacious enough for the movement of organelles such as mitochondria and microsomes. On this basis, the three sharp bands $D, G$, and $J$, a diffused band $C$, and a weak band $A$ should be corresponded to the major soluble proteins in the cytoplasm. With the exception of band $G$ which is glycoprotein in nature, the remaining cytoplasmic proteins were disintegrated during air-curing.

There are at least nine anodic bands common to the three organelles analyzed. The banding patterns were sharp in a light background. This indicates a minimal interference of the polyphenol and oxidase reaction in the organelle extracts. On the basis of dry weight, the mitochondrial fraction yielded more soluble proteins than chloroplasts; and nuclear extract showed the least amount. A weak band migrating slightly behind band $\mathrm{K}$ was observed in the mitochondrial extract 
only. In addition, its band $G$ was more intense than band $\mathrm{H}$, which reversed the pattern of choloplast extracts. One may argue the possible contamination of chloroplast fragments in the mitochondrial fraction. By the present cell fractionation procedures the amount of chloroplast fragments sedimented together with mitochondria could not be out-proportioned. If this is true, the major soluble proteins in these organelles are identical. Although the nuclear fraction was completely free of chlorophyll by visual judgement its extremely weak bands may have resulted from the contamination of aggregated chloroplasts or mitochondria. However, the absence of specific bands rules out the possibility of relating any protein to the nuclei. In the present case, nuclear histones were not extractable.

By excluding cytoplasmic proteins (bands A, C, D, G, and J), the bands $F, H, I$, and $K$ have to be a part of the organelles. The appearance of cytoplasmic proteins in organelle extracts may be due to the binding of proteins on the surface of the organelles. Another possibility is that these proteins are synthesized in the cytoplasm and later incorporated into the organelles. If the contamination of organelle fragments and aggregates in cellular fractions remains insignificant, the same protein pattern may reflect their similarities in structure or function. It has been known that subcellular organelles differ in metabolic functions which are catalyzed by specific enzyme proteins generally in soluble form. The concentration of metabolic enzymes may not be large enough to distinguish themselves as discrete bands. In this regard, one must suspect some of these proteins to be structurally related; for instance, membrane proteins. This is in keeping with current views on the chemical composition of biological membranes. Laico et al. (6) have isolated a group of "miniproteins" (molecular weight about 5000) from membranes of different biological sources. Abundant quantities and extremely similar peptide maps of different biological membranes led them to propose that miniproteins are universal in biological membranes, play a fundamental role in membrane function, and may be products of similar genes in different organisms. To extend this generization one may reason that miniproteins from membranes within the same organism are possibly identical in amino acid sequence because they can be controlled by the same nuclear genes. Experimental procedures can cause irreversible aggregation of miniproteins and other protein components of the membrane. The resulting high molecular weight proteins (structural proteins) probably correspond to the electrophoretic bands. Therefore, the present results indicate that the organelles of tobacco leaf cells have a high degree of similarity in the chemical makeup of membrane proteins.

With the exception of a weak band $F$, the protein zymogram of the crude extract of immature leaves showed an additive pattern of the organelles and the cytoplasm as expected. In comparison with mature leaves (Fig. I) the banding patterns were alike with slight differences in intensity. Since bands $B$ and $E$ were observed neither in organelle extracts nor in cytoplasm, they may be associated with plasma membrane or cell wall. This coincides with the stability of these proteins before and after air-curing and with their chemical composition as glycoproteins as mentioned above. Bands $\mathrm{L}$ and $\mathrm{M}$ were present in the crude extracts only. Whether they are also associated with plasma membrane or cell wall can only be speculative. In view of their fast mobility and weak intensity: the possibility of being partially denatured proteins cannot be ruled out.

On the basis of present investigation, one may conclude that soluble protein patterns of tobacco leaves resolved with polyacrylamide gel disc electrophoresis merely show the major proteins in cytoplasm and some structural proteins in membrane and cell wall. All these proteins undergo disintegration during simulated air-curing conditions except three glycoprotein bands. The chemical composition of these glycoproteins is being investigated.

\section{SUMMARY}

Polyacrylamide gel disc electrophoresis revealed at least 13 anodic protein bands in leaf extracts of seven tobacco (Nicotiana tabacum L.) strains representing burley, Turkish, flue- and fire-cured types. Four major bands B, E, G, and $J$ were common in all strains. Weak bands varied slightly in mobility and in number among tobacco types. Studies of cell fractions of Burley 21 leaves yielded information that bands $A$, $C, D, G$, and $J$ are present in the cytoplasm, whereas all but bands $B, E, L$, and $M$ appeared to be identical in the chloroplast, mitochondrial, and nuclear extiacts. The resemblance in protein banding pattern among the organelles indicates similarity in their membrane proteins. Bands B, E, L, and $\mathrm{M}$ are associated with plasma membrane or cell wall. During simulated air-curing, a majority of bands diminished by the tenth day, whereas bands $B, E$, and $G$ remained highly intense and the concentration of band $C$ was reduced in cured leaves. Bands $B, E$, and $G$ reacted positively with the periodic-acid Schiff's reagent (PAS) but negatively with the colloidal ion staining. Trypsin digestion abolished protein bands stained with amido black or the PAS reagent. Results suggest that bands B, $E$, and $G$ are neutral or weakly acidic glycoproteins.

\section{ZUSAMMENFASSUNG}

Die Untersuchung der Blattextrakte von sieben Linien von Nicotiana tabacum L. (Burley -, flue-cured -, firecured - und türkische Tabakarten) durch Polyacrylamidgel-disc. - Elektrophorese führte zum Nachweis von zumindest 13 anodischen Eiweißbanden. Vier Hauptbande $B, E, G$ und $J$ waren in den Blattextrakten aller sieben Linien nachweisbar. Schwache Banden variierten in geringem Maßse hinsichtlich ihrer Mobilität und ihrer Anzahl bei dem Vergleich der verschiedenen Tabakarten. 
Untersuchungen an Zellfraktionen von Burley-21-Blättern zeigten, daß die Banden A, C, D, G und J im Zytoplasma auftreten und $\mathrm{daß}$ dagegen die übrigen Banden, ausgenommen B, E, L und M, in den Extrakten der Chloroplasten, Mitochondrien und Zellkernen identisch zu sein scheinen. Die Ähnlichkeit der Eiweißbanden der Organellen weist auf eine Ähnlichkeit ihrer Membraneiweiße hin. Die Banden B, E, L und $M$ stehen in einer Beziehung zur Plasmamembran oder zur Zellwand. Im Verlaufe einer simulierten Lufttrocknung verminderte sich die überwiegende $\mathrm{Zahl}$ von Banden etwa am Io. Tag; die Banden B, E und G behielten dagegen ihre hohe Intensität, und die Konzentration der Bande C nahm in getrockneten Blättern ab. Die Banden B, E und $G$ reagierten auf das Perjodsäure-Schiff-Reagens (PAS) positiv, auf eine kolloidale Ionenfärbung hingegen negativ. Der Trypsinabbau brachte die Eiweißbanden, die mit dem Amidoschwarz oder dem PAS-Reagens behandelt worden waren, zum Verschwinden. Die Ergebnisse weisen darauf hin, daß es sich bei den Banden B, E und G um neutrale oder schwach saure Glykoproteide handelt.

\section{RESUME}

Par électrophorèse sur gel de polyacrylamide, on a trouvé au moins treize bandes anodiques de protéines dans les extraits des feuilles de sept lignées de tabac (Nicotiana tabacum L.) de type Burley, Turkish, flue- et fire-cured. Quatre bandes principales (B, E, G et J) sont communes à toutes les lignées. Les bandes faibles varient légrèment en mobilité et en nombre suivant les types de tabac. En étudiant des extraits cellulaires de feuilles Burley 21, on a observé les bandes A, C, D, G et J dans le cytoplasme, alors que toutes les autres bandes sauf $B, E, L$ et $M$ sont identiques dans les extraits de chloroplaste, mitochondries, et de noyaux. La ressemblance des schémas protéiniques dans les différentes organelles indiquent une similarité dans les protéines de leur membrane. Les bandes B, E, L et $M$ sont associées à la membrane cytoplasmique et à la membrane cellulaire. Dans des conditions d'air-curing, la plupart des bandes s'affaiblissent vers le dixième jour, alors queles bandes $B, E$ et $G$ restent très intenses, et que la bande $C$ s'affaiblit dans les feuilles séchées. Les bandes-
$B, E$ et $G$ réagissent positivement au réactif de Schiff à l'acide périodique (PAS), mais négativement à la coloration colloïdale ionique. L'action de la Trypsinesupprime les bandes colorées au noir basique ou au réactif de Schiff. Les résultats suggèrent que les bandes $B$, $E$ et $G$ sont des glycéroprotéines neutres ou légèrement acides.

\section{REFERENCES}

1. Axelrod, B., and Jagendorf, A. T.: Plant Physiol. 26 (I95I) 406

2. Davis, B. J.: N.Y. Acad. Sci. Ann. 121 (I964) 404.

3. Honold, G. R.; and Stahmann, M. A.: Cereal Science Today 14 (1969) 48 (Abst.).

4. Kawashima, N., and Wildman, S. G.: Ann. Review Plant Physiol. 21 (I970) 325.

5. Kawashima, N., Imai, A., and Tamaki, E.: Plant and Cell Physiol. 8 (1967) 595.

6. Laico,M. T., Ruoslahti, E. I., Papermaster, D. S., and Dreyer, W. J.: Proc. Nat. Acad. Sci. USA 67 (1970) 120.

7. Lowry, O. H., Rosebrough, N. J., Farr, A. L., and Randall, R. J.: J. Biol. Chem. I93 (I95I) 265.

8. Mowry, R. W.: Lab. Invest. 7 (1958) 566.

9. Narise, S., and Sakai, K. I.: Ann. Rept. Nat. Inst. of Genetics, Japan 17 (I966) 3I.

10. Pogell, B. M., Mosely, J. M., Likes, C. J., and Koenig, D. F.: Tob. Sci. I (1967) I38.

II. Sheen, S. J.: Theoret. Appl. Genetics 40 (I970) 18.

12. Sheen, S. J., and Calvert, J.: Plant Physiol. 44 (I969) I99.

13. Singer, S. J., Eggman, L., Campbell, J. M., and Wildman, S. G.: J. Biol. Chem. 197 (1952) 233.

14. Spencer, D., and Wildman, S. G.: Biochem. 3 (1964) 954 .

15. Stokes, G. W.: Science I4I (I963) 1185.

I6. Zelitch, I., and Zucker, E. M.: Plant Physiol. 33 (1958) 151.

The authors' address:

Department of Agronomy, University of Kentucky, Lexington, Kentucky, 40506, USA. 